\title{
Response of Marigold (Tagetes erecta l.) to Different Levels of Nitrogen at Bagh E Naran Park Peshawar
}

\author{
Shafiullah"*, Muhammad Ibrahim², Faraz Ali Shah"1, Taimor Khan', Israr Ahmad", Muhammad Awais Shahid ${ }^{1}$ \\ and Sajjad Khan ${ }^{1}$
}

${ }^{1}$ The University of Agriculture Peshawar-Pakistan

${ }^{2}$ Agriculture Research Station, Amnawar Buner KP-Pakistan

Submission: August 01, 2018; Published: August 14, 2018

*Corresponding author: Shafiullah, The University of Agriculture Peshawar-Pakistan, Email: shafiullah.ummathi@gmail.com

\begin{abstract}
An experiment on "Response of marigold to different levels of nitrogen" was carried out at the Horticulture Nursery, The University of Agriculture Peshawar, during 2013. Seedling of Marigold cultivar "Pygmy" were raised and transplanted on flat beds on $10^{\text {th }}$ October 2013 at 30 $\mathrm{cm}$ Plant to Plant and $60 \mathrm{~cm}$ Row to Row. The seedlings were subjected to four different levels of nitrogen, $70 \mathrm{~kg} \mathrm{ha}^{-1}, 90 \mathrm{~kg} \mathrm{ha}^{-1}$ and $110 \mathrm{~kg} \mathrm{ha}^{-1}$ along with the control with no nitrogen. Data were collected on plant height, number of branches, number of leaves, days to flowering, number of flowers and flower weight. Different level of nitrogen had significantly affected all the parameters mentioned below except number of leaves plant $^{-1}$. Maximum plant height (22.80 cm), maximum number of branches plant ${ }^{-1}(15.47)$, maximum number of leaves plant ${ }^{-1}(158.67)$, minimum number of days to flowering (22.33), maximum number of flowers plant ${ }^{-1}$ (23.22), maximum flower weight (20.66 gm), were recorded in plants received nitrogen at the rate of $110 \mathrm{~kg} \mathrm{ha}^{-1}$. Hence Marigold should be supplied with nitrogen at the rate of $110 \mathrm{~kg} \mathrm{ha}^{-1}$ in Peshawar valley.
\end{abstract}

Keywords: Tagetes erecta; Nitrogen levels; Response

\section{Introduction}

Marigold (Tagetes erecta L.), a member of the family Asteraceae or Compositae, is a potential commercial flower and its demand is increasing in the subcontinent [1]. Marigold is grown as ornamental flower. It is also one of the most important natural sources of xanthophyll for use as natural food additive to brighten egg yolks and poultry skin [2]. Marigold is a medicinal and ornamental plant. It is used for its cosmetic and medicinal properties. The essential oil of the flower contains antioxidants [3]. Marigold is also being used effectively to dye fabrics commercially, where its ethanol based flower extracts produce different colors on fabrics [4]. Marigold has been most commonly used by the poultry industry to augment the xanthophyll present in corn and alfalfa feed to standardize the feed's xanthophyll contents [5].

In South Asia they are in great demand of marigold during religious festival, where they used to adorn statues and building, also used in ceremonies and weddings. Loose flowers are sold in the markets which are mainly used in making garlands. The flowers are also used as cut flowers arrangement. Furthermore, Marigold is grown for beautification as a landscape plant due to its variable height and various colors of flowers. It is highly suitable as a bedding plant in herbaceous border and is ideal for newly planted shrubbery to provide color and fill space. French marigold is ideal for rockeries, endings, hanging baskets and window boxes. Both leaves and flowers are equally important from the medicinal point of view [6].
Proper combination of fertilizers plays a vital role in production of vigorous plants having maximum number of shoots and leaves, which have a positive impact on quality flower production and prolonged flowering period. Optimum cultural practices are necessary for quality flower production. Among essential nutrients, nitrogen, phosphorus, and potassium are most important for plant growth and flowering. These also play a key role in the higher production and seed yield of ornamental flowers [7]. Nitrogen enhances the vegetative growth and assists the plant during the blooming period to mobilize the process of flower opening. Flowering can be increased with increased levels of $\mathrm{N}$ application [8]. In marigold, plant vigor was decreased as the season progressed, which was attributed to nitrogen deficiency. Moreover, pigment yield was increased to the maximum by 3 nitrogen applications in a single season [9].

Nitrogen is integral part of the plant tissues, and has direct and positive effects on the crop growth and performance [10]. Excess amount of $\mathrm{N}$ in some cases have adverse or nil effects on plant growth [11]. $\mathrm{N}$ fertilization in huge amount causes imbalance in $\mathrm{N}$ system, low yield and ultimately more losses of $\mathrm{N}$ [12]. Proper nutrients provision is essential for successful cultivation of Marigold. With the application of nitrogen (N), the number of flowers per plants and flower yield increases. Keeping in view the importance of nitrogen for the marigold, this experiment was 
designed to find out optimum dose of nitrogen for maximum and quality production/yield of Marigold.

\section{Objective}

To investigate the optimum nitrogen level for growth parameters of Marigold at the climatic conditions of Peshawar.

\section{Materials and Methods}

An Experiment was conducted to study "The response of Marigold to different levels of nitrogen", at the Horticulture Nursery, The University of Agriculture Peshawar, during 2013. Nursery was set up and seeds were sown on raised beds on $10^{\text {th }}$ September, the seeds were germinated up to $18^{\text {th }}$ September. On 10th October seedlings were transplanted into well prepared beds having $30 \mathrm{~cm}$ Plant to Plant and $60 \mathrm{~cm}$ Row to Row distance. The experimental plot was thoroughly ploughed before transplantation. The experiment was laid out in Randomized Complete Block Design (RCBD) having three replications. Nitrogen was applied at four (4) different levels i.e. 0, 70, 90, $110 \mathrm{~kg} \mathrm{ha}^{-1}$ to the plots. All cultural practices like weeding, hoeing and irrigation etc were kept uniform. The fertilizer used as source of $\mathrm{N}$ was urea and plot size of each experimental unite was $1.4 \mathrm{~m}^{2}$.

\section{Results and Discussion}

\section{Plant Height (cm)}

Data regarding plant height of marigold as affected by different levels of nitrogen is shown in Table 1. According to statistical analysis, plant height was significantly affected by different nitrogen levels. Maximum plant height $(22.80 \mathrm{~cm})$ was recorded with the application of $110 \mathrm{~kg}$ of $\mathrm{N} \mathrm{ha}^{-1}$, while the minimum plant height $(19.22 \mathrm{~cm})$ was recorded with control treatment. This may be due to the fact that nitrogen application enhances metabolic process and results in maximum plant height. Malik reported that basically nitrogen is part of chlorophyll, proteins which enhance plant vegetative growth [13].

\section{Number of Branches}

Table 1: Plant Height (cm), Number of Branches and Number of leaves of marigold as affected by Nitrogen Levels.

\begin{tabular}{|c|c|c|c|}
\hline Treatments & $\begin{array}{c}\text { Plant Height } \\
\text { (cm) }\end{array}$ & $\begin{array}{c}\text { Number of } \\
\text { Branches }\end{array}$ & $\begin{array}{c}\text { Number of } \\
\text { leaves }\end{array}$ \\
\hline Control & $19.22 \mathrm{c}$ & $12.88 \mathrm{c}$ & 149.67 \\
\hline N1 $(70 \mathrm{~kg})$ & $20.40 \mathrm{~b}$ & $14.55 \mathrm{~b}$ & 155.33 \\
\hline N2 $(90 \mathrm{~kg})$ & $21.88 \mathrm{a}$ & $15.00 \mathrm{ab}$ & 157.27 \\
\hline N3 $(110 \mathrm{~kg})$ & $22.80 \mathrm{a}$ & $15.47 \mathrm{a}$ & 158.67 \\
\hline
\end{tabular}

Data pertaining to number of branches of marigold as affected by different levels of nitrogen is shown in Table 1. According to statistical analysis, number of branches was significantly affected by different nitrogen levels. Maximum number of branches plant ${ }^{-1}$ (15.47) was counted with the application of $110 \mathrm{~kg}$ of $\mathrm{N} \mathrm{ha}^{-1}$ while minimum numbers of branches (12.88) were counted with control treatment. It is because of fact that with more application of nitrogen plant shows vigorous vegetative growth. The results are in agreement with [14] who reported that higher nitrogen level increase plant growth.

Number of Leaves Plant ${ }^{-1}$ : Data regarding numbers of leaves as affected by different levels of nitrogen is shown in Table 1. According to statistical analysis, number of leaves was nonsignificantly affected by different nitrogen levels.

\section{Days to Flowering}

Data regarding days to flowering of marigold as affected by different levels of nitrogen is shown in Table 2. According to statistical analysis, Days to flowering was significantly affected by different nitrogen levels. Delayed (27.99 days) flowering was observed with application of $110 \mathrm{~kg} \mathrm{~N} \mathrm{ha}^{-1}$ fallowed by 26.143 days @ $90 \mathrm{~kg} \mathrm{~N} \mathrm{ha}^{-1}$ while early flowering (22.33 days) was observed at control plots (with no application of nitrogen). It might be due to the fact that an increase in nitrogen increases vegetative growth and hence delayed reproductive phase. The results are in agreement with Malik who reported that higher nitrogen dose delayed flowering [14].

Table 2: Days to flowering, Number of Flowers Plant ${ }^{-1}$ and Flower Weight (gm) of marigold as affected by nitrogen levels.

\begin{tabular}{|c|c|c|c|}
\hline Treatments & $\begin{array}{c}\text { Days to } \\
\text { Flowering }\end{array}$ & $\begin{array}{c}\text { Number of } \\
\text { Flowers Plant }\end{array}$ & $\begin{array}{c}\text { Flower Weight } \\
\text { (gm) }\end{array}$ \\
\hline Control & $22.33 \mathrm{~d}$ & $17.99 \mathrm{~b}$ & $14.53 \mathrm{~b}$ \\
\hline N1 $(70 \mathrm{~kg})$ & $24.33 \mathrm{c}$ & $22.66 \mathrm{a}$ & $17.87 \mathrm{ab}$ \\
\hline N2 $(90 \mathrm{~kg})$ & $26.14 \mathrm{~b}$ & $22.88 \mathrm{a}$ & $20.16 \mathrm{a}$ \\
\hline N3 $(110 \mathrm{~kg})$ & $27.99 \mathrm{a}$ & $23.22 \mathrm{a}$ & $20.66 \mathrm{a}$ \\
\hline
\end{tabular}

\section{Number of Flowers Plant ${ }^{-1}$}

Data pertaining to numbers of flowers per plant is shown in Table 2. Statistical analysis shows that numbers of flowers ${ }^{-1}$ plant were significantly affected by nitrogen levels. Maximum number of flowers plant ${ }^{-1}(23.22,22.88,22.66)$ were recorded with the application of (110, 90 and $\left.70 \mathrm{~kg} \mathrm{~N} \mathrm{ha}^{-1}\right)$, and minimum number of flowers plant ${ }^{-1}$ (17.99) was recorded with control. This might be due to reduced number of leaves, and branches plant ${ }^{-1}$. Similar results had been reported. Means followed by different letters are significantly different from one another.

Flower Weight (gm): Data regarding flower weight of marigold as affected by different level of nitrogen is shown in Table 2. According to statistical analysis, flower weight was significantly affected by different nitrogen levels. Maximum weight of flower (20.66 gm and $20.16 \mathrm{gm}$ ) was recorded with the application of (110 kg N ha-1 and $90 \mathrm{~kg} \mathrm{~N} \mathrm{ha}^{1}$ ) and minimum weight of flower (17.87 gm and $14.53 \mathrm{gm}$ ) was recorded with the application of (70 $\mathrm{kg} \mathrm{N} \mathrm{ha}{ }^{1}$ and $0 \mathrm{~kg} \mathrm{~N} \mathrm{ha}^{1}$ ). This may be due to the reason that nitrogen application enhances metabolic process and results in increase flower weight.

\section{Summary}

The Experiment was conducted to study "The response of Marigold to different levels of nitrogen", at the Horticulture Nursery, The University of Agriculture Peshawar, during 2013. Seedling of 
Marigold cultivar "Pygmy" were raised and transplanted on flat beds well having $30 \mathrm{~cm}$ Plant to Plant and $60 \mathrm{~cm}$ Row to Row distance. The experiment was laid out in Randomized Complete Block Design (RCBD) having three replications. Nitrogen was applied at four (4) different levels i.e. $0,70,90,110 \mathrm{~kg} \mathrm{ha}^{-1}$ to the plots. The fertilizer used as source of $\mathrm{N}$ was urea and plot size of each experimental unite was $1.4 \mathrm{~m}^{2}$. Data were collected on plant height, number of branches, number of leaves, days to flowering, number of flowers and flower weight.

Different level of nitrogen had significantly affected all the parameters mentioned below except number of leaves plant ${ }^{-1}$. Maximum plant height $(22.80 \mathrm{~cm})$, number of branches plant ${ }^{-1}$ (15.47), number of leaves plant ${ }^{-1}$ (158.67), number of flowers plant $^{-1}$ (23.22), flower weight (20.66 gm) and the minimum number of days to flowering (22.33) were recorded in plants received nitrogen at the rate of $110 \mathrm{~kg} \mathrm{ha}^{-1}$. While the minimum plant height $(19.22 \mathrm{~cm})$, number of branches plant ${ }^{-1}$ (12.88), number of leaves plant ${ }^{-1}$ (149.67), number of flowers plant ${ }^{-1}$ (17.99) and the minimum flower weight (14.53 gm) were observed in Control treatment i.e. 0 kg Nitrogen applied.

\section{Conclusion}

From the observed results and their analysis, it can be concluded that Marigold plant cultivar Pygmy received nitrogen (N) @ $110 \mathrm{~kg} \mathrm{ha}^{-1}$ significantly affected Maximum plant height $(22.80 \mathrm{~cm})$, number of branches plant ${ }^{-1}(15.47)$, number of leaves plant $^{-1}$ (158.67), number of flowers plant ${ }^{-1}$ (23.22), flower weight (20.66 gm) and the minimum number of days to flowering (22.33).

\section{Recommendations}

Hence on the basis of above conclusions it could be recommended that nitrogen should be applied at the rate of 110 $\mathrm{kg} \mathrm{ha}^{-1}$ to Marigold plants in Peshawar valley.

\section{References}

1. Abril A, D Baleani, N Casado-Murillo, L Noe (2007) Effect of wheat crop fertilization on nitrogen dynamics and balance in the Humid Pamps. Argentina Agric Ecosyst And Environ 119: 171-176.
2. Anamika, ML Lavania (1990) Effect of nitrogen, phosphorus and potassium on growth, yield and quality of rose. Haryana J Hort Sci 19: 291-298.

3. Asano T, Y Tanaka, Mizuta (1982) Effect of nitrogen and potassium on marigold production and function. Bulletin the Nara Agriculture Experiment Station 12: 43-47.

4. Asif M (2008) Effect of Various NPK Levels on Growth, Yield and Xanthophyll Contents of Marigold. MSc Thesis, Inst of Hort Sci, Univ of Agric, Faisalabad, Pakistan, p. 95.

5. Baldwin RE, CM Waldenmaier, RC Lambe (1993) Marigold research report 1986-1993. Va Polytechnic Inst and State Univ, Painter, VA.

6. Bosma TL, JM Dole, NO Maness (2003) Crop ecology, management and quality: Optimizing marigold (Tagetes erecta L.) petal and pigment yield. Crop Sci 43: 2118-2124.

7. Delgado-Vargas F, O Paredes-Lopez, E Avila-Gonzalez (1998) Effect of sunlight illumination on marigold flowers meals and egg yolk pigmentation. J Agric Food Chem 46: 698-706.

8. Fan MF, R Jiang, X Liu, F Zhang, S Lu, et al. (2005) Interaction between noon-flooded mulching cultivation and varying nitrogen inputs in rice-wheat rotations. Field Crops Res 91: 307-318.

9. Kashif N (2001) Effect of NPK on growth and chemical effect on Vaselife of Zinnia. MSc Thesis, PMAS Arid Agri, Univ, Rawalpindi, Pakistan, p. 23.

10. Malhi SS, R Lemke, ZH Wang, BS Chhabra (2006) Tillage, nitrogen and crop residue effects on crop yield, nutrient uptake, soil quality, and greenhouse gas emissions. Soil and Tillage Res 90: 171-183.

11. Malik MN (1994) Floriculture and Landscape gardening. Horticulture. National Book Foundation, Islamabad 5: 546-547.

12. Perez GRM, H Luha, SH Garrido (2006) Antioxidant activity of Tagetes erecta essential oil. J Chile Chem Soc 51(2): 883-886.

13. Singh RP, RP Srivastara, KP Phoghat (1984) Studies on foliar nutrition of marigold. Punjab Hort Journal 23(1-2): 64-68.

14. Vankar PS, R Shanker, S Wijayapala (2009) Utilization of temple waste flower - Tagetes erecta for dyeing of cotton, wool and silk on industrial scale. J Textile Apparel Tech Manag 6: 1-15.

\section{Your next submission with Juniper Publishers} will reach you the below assets

- Quality Editorial service

- Swift Peer Review

- Reprints availability

- E-prints Service

- Manuscript Podcast for convenient understanding

- Global attainment for your research

- Manuscript accessibility in different formats ( Pdf, E-pub, Full Text, Audio)

- Unceasing customer service

Track the below URL for one-step submission https://juniperpublishers.com/online-submission.php 